\title{
DINAMIKA KELOMPOK SEBAGAI ALTERNATIF PEMBELAJARAN MATEMATIKA UNTUK MENINGKATKAN KEMANDIRIAN, PARTISIPASI DAN PRESTASI BELAJAR SISWA
}

\author{
Oleh \\ Muhammad Juaini \\ Email: muhammadjuaini@gmail.com
}

\begin{abstract}
ABSTRAK
Tujuan penulisan ini adalah untuk mengetahui apakah dalam menerapkan Dinamika kelompok dapat meningkatkan angka kemandirian, dan prestasi belajar kelas X IPS-1 semester Genap Tahun Pelajaran 2018/2019 di SMA Negeri 3 Selong dapat meningkat. Penulisan ini melibatkan 32 orang siswa yang dilaksanakan berdarkan SK pembagian Tugas Tp 2018/2019. Pengumpula Data dilakukan dengan pengamatan, foto-foto kegiatan, kejadian dan komentar dari subyek yang diteliti serta tes hasil belajar siswa sebanyak tiga siklus. Hasil yang diperoleh terdapat peningkatan angka kemandirian, angka partisipasi dan prestasi belajar siswa yang cukup signifikan sehingga hasil penulisan ini layak untuk dikaji dan dijadikan sebagai alternative pembelajaran matematika.
\end{abstract}

\section{Kata Kunci : pembelajaran matematika, prestasi belajar}

\section{PENDAHULUAN}

Rendahnya mutu pendidikan selama ini sering menjadi keluhan banyak pihak, setidaknya dilihat dari banyaknya siswa yang tidak lulus ujian akibat dari perolehan nilai mata pelajaran yang di UNBK-kan termasuk matematika, yang belum mencapai standar kelulusan yang ditetapkan pemerintah. Dilain pihak masih terdengar berbagai keluhan siswa mengenai kesulitan belajar matematika, dari berbagai tingkatan rombongan dan berbagai jenjang pendidikan. Sebagai konsekuensi dari kesulitan belajar matematika, hingga kini masih sering mata pelajaran tersebut tegolong sebagai pelajaran yang kurang menyenagkan oleh sebagian anggota rombongan belajar di sekolah ini. Menurut data prolehan nilai $\mathrm{UNBK}^{1}$ ditemukan bahwa Peringkat SMAN 3 Selong berdasarkan prolehan nilai

\footnotetext{
${ }^{1}$ Data nilai UNBK SMAN 3 Selong Tahun 2018/2019
} 
nilai matematika dari seluruh SMA Negeri dan Swasta di Kabupaten Lombok Timur berada pada urutan 17 dari 26 sekolah yang ada. Selanjutnya berdasarkan temuan data $^{2}$ ditemukan tingkat ketuntasan belajar matematika kelas X IPS-1 mengalami kemunduran yaitu, sebesar $57 \%$. Rendahnya angka ketuntasan belajar yang dicapai siswa atau banyaknya peserta yang belum memenuhi target angka ketuntasan, bukan disebabkan semata-mata siswa mengalami kesulitan belajar, tetapi juga ada permasalahan lain yaitu kurangnya aktivitas, kreativitas dan partisipasi siswa dalam mengikuti proses pembelajaran. Selain itu meskipun selama ini guru telah mengenal berbagai tiori dan metode pembelajran, namun masih dirasakan minimnya upaya guru untuk membantu peserta didik yang mengalami kesulitan belajar, keterampilan guru dalam penerapan metode pembelajaran belum maksimal turut menjadi penyebab lainya. Padahal aktivitas, kreativitas, partisipasi dan keterampilan dalam penerapan metoe pembelajaram merupakan sesuatu yang sangat penting dalam kegiatan proses belajar mengajar. Sebagai konsekuensi logis dari kondisi tersebut adalah mutu proses pembelajaran dengan melibatkan hal-hal yang terkait dengan aktivitas, kreativitas, partisipasi dan perbaikan metode pembelajaran tentu prestasi belajar siswa menjadi lebih tidak baik. Meskipun hal yang menjadi penyebab berbagi keslitan belajar siswa, seperti disebutkan di atas telah ditangani selama ini oleh pihak guru, baik kualitas maupun kuantitasnya, sehingga kondisi saat ini oleh sebagaian pendidik dirasakan lebih baik daripada kondisi sebelumnya, namun mutu pembelajaran dan prestasi belajar siswa SMAN 3 Selong seperti yang diinginkan kurikulum belum terwujud. Disamping itu penulis belum menemukan adanya ulasan dan penulisan yang mengarah pada penggunaan pendekatan dinamika kelompok sebagai alternatif pembelajaran sehingga seolah-olah hal tersebut selama ini belum mendapatkan perhatian. Bardasarkan uraian di atas maka penulis merasa tertarik untuk melakukan kajian dengan menerapkan Pembelajaran Dinamika Kelompok sebagai alternatif metode belajar, sebagai upaya untuk meningkatkan kemandirian, partisispasi dan prestasi belajar siswa kelas X IPS-1 SMAN 3 Selong Lomok Timur, sehingga mereka lebih terampil memecahkan masalah,

${ }^{2}$ Leger nilai kelas X IPS-1 semester ganjil tahun 2018/2019 
cermat menganalisis data, berpikir secara logis, cermat dalam membuat keputusan serta memiliki kepekaan sosial yang tinggi.

\section{METODOLOGI PENULISAN}

\section{Desain Penelitian}

Desain penulisan ini menggunakan model Kemmis dan Tanggart dengan tahapan perencanaan, tindakan dan pengamatan serta refleksi untuk setiap siklus. Untuk memecahkan permasalahan akan dilakukan serangkaian tindakan dalam bentuk siklus-siklus, sebanyak 3 (tiga) siklus. Setiap siklus memiliki tahapan sebagai berikut:

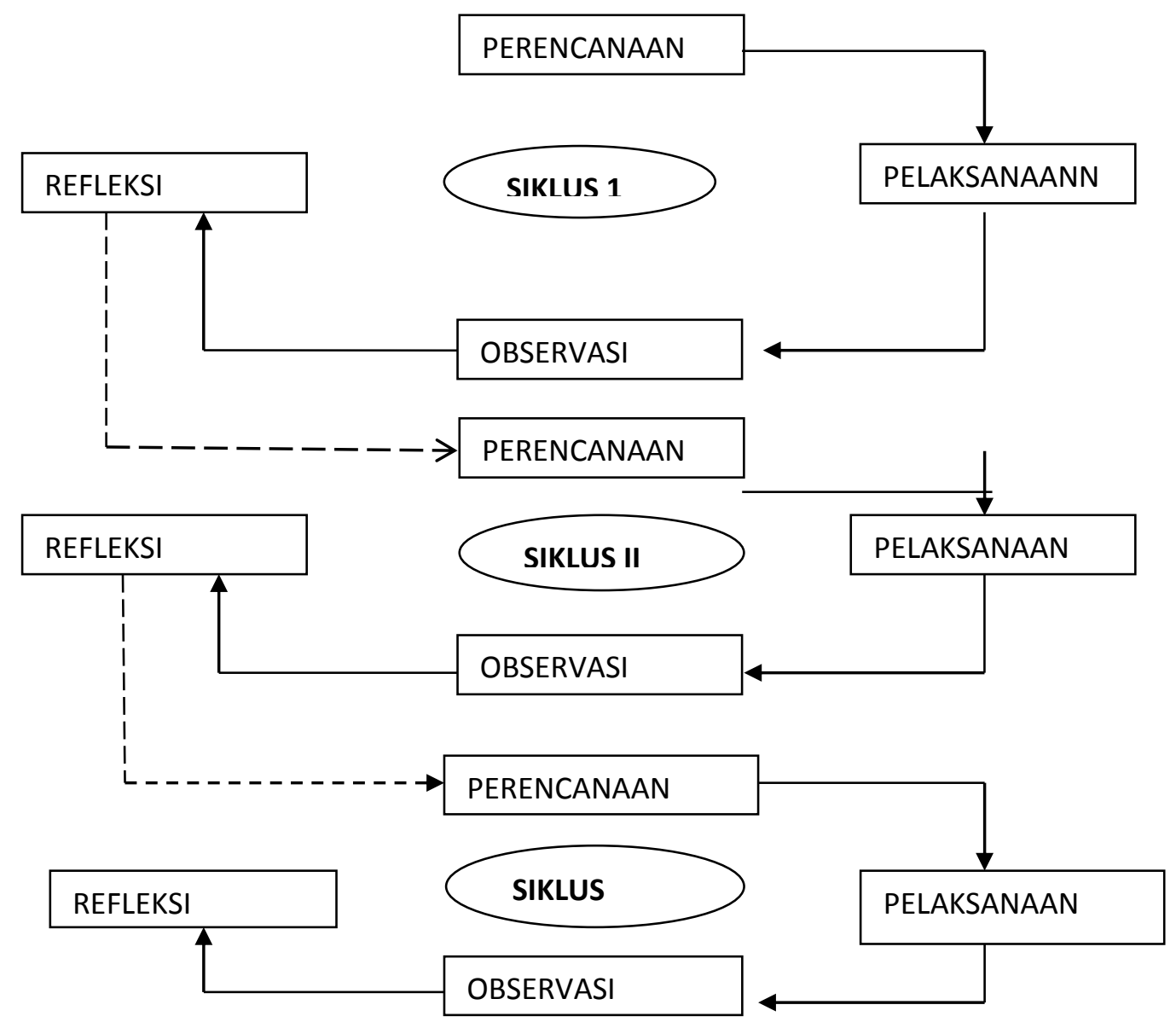

Gambar : Setting Penulisan Model Dinamika Kelompok 


\section{Analisis Data}

Analisis data dilakukan dengan teknik kualitatif dan kuantitatif. Analisis kualitatif dilaksanakan secara terus menerus, sejak melakukan kegiatan penulisan di kelas XII IPA dari awal kegiatan pembelajaran hingga akhir kegiatan, begitu data terkumpul langsung dianalisis agar diperoleh kejelasan setiap siklus. Analisis data dalam penulisan kualitatif merupakan proses penyederhanaan data ke dalam bentuk yang lebih mudah dibaca dan di interpretasikan. Adapun kegitan yang dilakukan penulis dalam analisis data dimulai darai pengecekan keabsahan data. Pengecekan keabsahan data dalam penulisan kualitatif merupakan hal penting dalam upaya memenuhi kesahehan data penulisan.

Adapun sajian data disajikan dalam bentuk naratif, yang disusun dari hasil reduksi data. Data yang disajikan merupakan sekumpulan informasi, sehingga dalam hal ini penulis memungkinkan dapat menarik kesimpulan atau mengambil tindakan lebih lanjut berdasarkan sekumpulan informasi tersebut yang diperoleh dari hasil reduksi data. Penyajian data dalam penulisan ini dilakukan dengan mengacu pada fokus penulisan.

Selanjutnya Penulis dalam hal ini berusaha untuk mencari makna dari data yang telah disajikan untuk ditarik menjadi suatu kesimpulan. Kesimpulan yang diperoleh mula-mula bersifat tentatif, artinya mungkin saja kurang jelas dan diragukan pada siklus tahap awal akan tetapi semakin bertambahnya siklus yang dilalui, akan diperoleh data yang berasal dari observasi, maka kesimpulan yang diperoleh diharapkan menjadi lebih mengakar dan kokoh. Penarikan kesimpulan dilakukan dalam penulisan ini terkonsentrasi pada fokus penulisan yang meliputi simpulan tentang tentang keterlibatan dan kemandirian siswa dalam penggunaan dinamika kelompok dalam kegiatan belajar mengajar. Sementara analisis data kuantitatif meliputi: Mengecek nama dan kelengkapann identitas pengisi jawaban dimaksudkan untuk keperluan pengolahan data lebih lanjut. Mengecek kelengkapan data artinya memeriksa isi instrumen pengumpulan data. Sedangkan tabulasi meliputi: tabulasi data dalam bentuk tabel sehingga memudahkan dalam pembacaan hasil, penyimpulan data,dan penarikan kesimpulan. Selanjutnya Analisis data tertumpu pada kegiatan analisis deskriftif. Analisis Deskriptif adalah 
dimaksudkan untuk menyajikan data dari setiap variabel dalam besaran-besaran statistik deskrifif, yang meliputi nilai rata-rata (mean $)^{3}$.

$$
\begin{aligned}
\bar{X} & =\frac{\sum f x}{n} \\
\bar{X} & =\text { nilai rata }- \text { rata } \\
X & =\text { nilai amatan } \\
N & =\text { banyaknya amatan }
\end{aligned}
$$

\section{PEMBAHASAN}

\section{Siklus I}

Dalam tahap ini diperoleh data mengenai keterlibatan siswa sebagai berikut dari 32 orang siswa yang dijadikan sebagai subyek penulisan terdapat 20 orang yang terlihat secara aktif selama kegitan belajar sementara sisanya 13 orang belum menunjukkan kemajuan yang berarti. Hal ini diperoleh dari data keterlibatan siswa yang ikut terlibat langsung ketika guru, presentator dan siswa lainya. Indikator yang mengarah kapada asfek keterlibatan langsung antara lain : Siswa mengajukan persoalan secara yang sedang dihadapi saat itu aktif, memiliki catatan dengan rapi, berkomunikasi lancar dengan sesama kelompok atau diluar kelompok, tidak ngantuk selama kegiatan berlangsung, tidak datang terlambat dan atau sengaja keluar untuk keperluan yang tidak jelas, bantuan yang diberikan kepada sesama kelompok. Pada siklus pertama ini dari sejak dilakukannya penulisan yang disertai dengan penerapan dinamika kelompok sebagai alternative metode pembelajaran ternyata hanya 20 orang yang selalu berbuat seperti yang disebutkan diatas. Meskipun ada diantara kelompok diluar 20 orang tadi memberikan respon seperti yang diajukan penulis namun tidak dikategorikan bermutu, sehingga respon mereka digolongkan rendah. Bila saja tingakat keterlibatan siswa ini digolongkan atas empat tingkatan yaitu $0 \mathrm{~s} / \mathrm{d} 49 \%$ rendah, 50 s/d $69 \%$ sedang, $70 \mathrm{~s} / \mathrm{d} 89 \%$ tinggi dan 90 s/d 100 sangat tinggi. Ini berarti ada 47,61 \% siswa yang terlibat aktif sedangkan 52,39\% belum menunjukan kemajuan yang berarti. Jadi dapat disimpulkan bahwa pada siklus pertama ini

${ }^{3}$ Sutrisno Hadi, Statistik Jilid II, (Yogyakarta, Andi: 2010) 
tingkat keterlibatan belajar siswa digolongkan rendah. Hal ini dapat diterima bahwa pada tahap ini siswa belum terbiasa menggunakan metode ini dalam kegiatan belajar megajar. Sesuai dengan pendapat diatas penulis menemukan selama kegiatan pembelajaran berlangsung pada siklus pertama ini telah terjadi bulliying dalam kegiatan pembelajaran di kelas X IPS-1 SMAN 3 Selong, padahal hal tersebut sangat tidak baik dalam dunia pendidikan. Bulliying menurut yatim $(2004,56)$ diartikan sebagai menghukum seseorang siswa ketika dalam suasana kegiatan pembelajaran. Selanjutnya dikatakan bahwa bentuk bulliying dapat saja berupa kegiatan metertawakan, meneriaki, menghardik, memukul dan tindakan negative lainya. Selanjutnya pada fokus penulisan mengenai aspek kemandirian siswa diperoleh gambaran sebagai berikut terdapat 13 orang siswa yang memiliki kemajuan yang berarti sementara sisanya 26 orang siswa belum menunjukkan kemandirian. Jadi dapat dikatakan bahwa lebih banyak perbandingan siswa yang belum menunjukan memiliki kemandirian dibangkan dengan yang sudah memiliki hal ini ditandai dengan lebih banyak siswa yang tidak:1) mengajukan berbagai solusi ketika menyelesaikan persoalan yang diajukan guru atau siswa, 2) ketepatan solusi yang ditawarkan, 3) mampu menerapkan materi yang telah dipelajari dan yang sedang dihadapi, 4) menawarkan berbagai cara untuk menyelesaikan persoalan yang dihadapi, 5) membuat teman diskusi tidak merasa direndahkan, 6) mampu menghubungkan materi pelajaran yang sedang dihadapi dengan materi lain, 7) mampu memberikan penjelasan kepada siswa lain dengan caranya sendiri, 8) mampu berdiskusi dengan baik, ketepatan komentar atas jawaban yang keliru oleh kelompok lain dan 9) mengajukan pertanyaan dan memberikan solusi ketika pertanyaan atau permasalah yang diajukan guru maupun siswa. Selain itu dalam pengamatan penili tentang kemajuan dari tahap ini ditemukan ada perbedaan antara keterlibatan dengan kemandirian siswa yaitu, meskipun siswa kelihaanya aktif namun belum tentu mandiri demikian sebaliknya. Tetapi jika kemandirian siswa sangat baik dapat diduga bahwa siswa tersebut akan lebih banyak terlibat dalam kegiatan diskusi. Dari dua pendapat diatas penulis melihat dengan cermat selama kegiatan sisklus pertama, penulis menyimpulkan bahwa: siswa yang aktif belum 
tentu mandiri tapi pada umumnya siswa yang aktif akan menunjukkan kemandirian yang baik yang baik. Selanjutnya jika saja tingkat kemandirian siswa pada tahap ini dikelompokkan atas tiga tingkatan yaitu bila banyak siswa; 1) antara $1 \mathrm{~s} / \mathrm{d} 10$ orang kurang, 2) antara $11 \mathrm{~s} / \mathrm{d} 20$ orang sedang , 3) antara $21 \mathrm{~s} / \mathrm{d}$ 30 orang baik dan , 4) antara 31 s/d 39 orang digolongkan sangat baik, maka pada tahap ini kemandirian siswa masih rendah. Hal tersebut diatas dapat diterima bahwa peserta didik di SMAN 3 Selong kelas X IPS-1 belum terbiasa atau belum dapat menerima metode yang diajukan penulis ini ditandai dengan banyaknya siswa yang belum memiliki peralatan yang memadai untk kepentingan pembelajaran seperti: 1) memiliki catatan dengan rapi, 2) alat tulis dan buku penunjang laninya selain modul dan LKS yang disediakan penulis, 4) belum mampu berkomunikasi lancar dengan sesama kelompok atau diluar kelompok, 5) adanya beberap siswa yang ditemukan mengantuk selama kegiatan berlangsung, 6) ditemukannya siswa yang datang terlambat dan atau sengaja keluar untuk keperluan yang tidak jelas, 7) belum banyaknya bantuan yang diberikan kepada sesama kelompok. Sementara menurut arikunto (2008; 81) mengatakan inti dari penulisan tindakan kelas itu bertumpu pada aktivitas siswa. Dengan demikian dapat dikatakan bahwa pada tahap siklus pertama ini belum dikatakn berhasil berdasarkan temuan penulis, pendapat beberapa orang siswa dan pendapat para ahli yang berkompeten dalam bidang ini. Adapun tingkat prestasi belajar siswa terdapat 15 orang siswa yang telah mencapai KKM sedangan sisanya 24 orang belum mencapai KKM. Bila saja tingkatan prestasi siswa ini digolongkan atas empat tingkatan berdasarkan pterpenuhinya KKM yang ditetapkan sebelumnya yaitu 0 s/d $49 \%$ rendah, $50 \mathrm{~s} / \mathrm{d} 69 \%$ sedang, $70 \mathrm{~s} / \mathrm{d} 89 \%$ tinggi dan $90 \mathrm{~s} / \mathrm{d}$ 100 sangat tinggi. Ini berarti bahwa lebih banyak siswa yang mengikuti remidi dibandingkan siswa yang tidak ikut remidi namun setelah dikompirmasi dengan keputusan diatas maka tingkat prestasi belajar siswa sedang. Sementara kemajuan prestasi belajar siswa yang diperoleh saat penulis ingin mengetahui apakah konsep yang ditanamkan, seberapa banyak siswa yang benar jawabanya ketika diadakan evaluasi ( formatif tes) jumlahnya masih sedikit bila dibandingkan dengan jawaban siswa yang salah atau siswa tidak menjawab sama 
sekali. Dari gambaran data diatas secara umum bahwa pada tahap ini belum berhasil secara umum meskipun pada variabel tertentu sudah berhasil, namun pada variabel lain masih banyak kekurangan. Untuk kepentingan itu penulisan ini dilanjutkan pada siklus kedua. Hal ini dapat diduga bahwa kreativitas dan prestasi belajar rendah tidak hanya disebabkab oleh faktor siswanya namun faktor guru dan lingkungan juga sangat mendukung sehingga penerapan metode ini belum optimal. Beberapa penyebab itu antara lain: 1) masih terdapat buliuying selama kegitan belajar mengajar berlangsung, siswa belum terbiasa berdiskusi, 2) guru belum terampil dalam mengajukan pertanyaan, 4) alat evaluasi setelah dianalisis tingkat kevaliditasnya kurang baik, 5) siswa belum terbiasa mempresentasikan hasil kerjanya, 6) adanya siswa yang memiliki: catatan tidak rapi, 7) berkomunikasi belum lancar dengan sesama kelompok atau diluar kelompok, 8) adanya siswa mengantuk selama kegiatan berlangsung, terlambat dan atau sengaja keluar untuk keperluan yang tidak jelas, 9) bantuan yang diberikan kepada sesama kelompok belum bermutu, 10) sedikit siswa yang mengajukan berbagai solusi ketika menyelesaikan persoalan yang diajukan guru atau siswa, 11) ketidak ketepatan solusi yang ditawarkan, 12) belum mampu secara umum menerapkan materi yang telah dipelajari dan yang sedang dihadapi, 13) masih sedikit siswa yang menawarkan berbagai cara untuk menyelesaikan persoalan yang dihadapi, 14) adanya perbuatan siswa yang membuat teman diskusi merasa direndahkan, 16) secara umum siswa belum mampu menghubungkan materi pelajaran yang sedang dihadapi dengan materi lain, 17) belum mampu memberikan penjelasan kepada siswa lain dengan caranya sendiri, 18) belum mampu berdiskusi dengan baik, masih ketidak ketepatan komentar atas jawaban yang keliru oleh kelompok lain.

\section{Siklus II}

Dalam tahap ini diperoleh gambaran data mengenai aktivitas siswa sebagai berikut dari 32 orang siswa yang dijadikan sebagai obyek penulisan terdapat 25 orang yang terlihat secara aktif selama kegitan belajar sementara sissanya 14 orang belum menunjukkan kemajuan yang berarti. Pada tahap ini telah ditemukan 
adanya kemajuan yang cukup berarti, bahwa aktivitas siswa menunjukkan adanya kemajuan pada sikap: memiliki catatan dengan rapi, berkomunikasi lancar dengan sesama kelompok atau diluar kelompok, tidak datang terlambat dan atau sengaja keluar untuk keperluan yang tidak jelas, namum bulliying dan mengantuk selama kegiatan berlangsung masih ditemukan meskipun berkurang jumlahnya termasuk aktivitas bantuan yang diberikan kepada sesama kelompok juga masih perlu perbaikan. Dari data yang diperoleh penulis secara cermat dapat disimpulkan bahwa mulai pada tahap ini metode sudah dapat diterima oleh sebagian besar peserta didik, meskipun harus diperbaiki. Bila saja data ini didiskripsikan dalam prosentase ada $65,1 \%$ siswa digolonkan aktif dan ada 34,9\% siswa tidak katif. Jadi dapat disimpulkan bahwa pada tahap ini tingkat keterlibatan belajar siswa digolongkan sedang, Hal ini dapat dilihat keterlibtan siswa yang ikut terlibat langsung ketika guru, presentator dan siswa lainya mengajukan persoalan. sejak secara aktif, memiliki catatan dengan rapi, berkomunikasi lancar dengan sesama kelompok atau diluar kelompok, tidak datang terlambat dan atau sengaja keluar untuk keperluan yang tidak jelas tetapi bulliying telang mulai berkurang. Selanjutnya pada fokus penulisan mengenai aspek kemandirian siswa diperoleh gambaran sebagai berikut terdapat 23 orang siswa yang memiliki kemajuan yang berarti sementara sisanya 16 orang siswa belum menunjukkan kemandirian yang menggembirakan hal ini ditandai dengan banyaknya siswa yang belum dapat: mengajukan berbagai solusi ketika menyelesaikan persoalan yang diajukan guru atau siswa, mengungkapkan ketepatan solusi yang ditawarkan, menerapkan materi yang telah dipelajari dan yang sedang dihadapi, menawarkan berbagai cara untuk menyelesaikan persoalan yang dihadapi, mampu menghubungkan materi pelajaran yang sedang dihadapi dengan materi lain. Akan hanya dengan asfek membuat teman diskusi tidak merasa direndahkan, mampu memberikan penjelasan kepada siswa lain dengan caranya sendiri, berdiskusi dengan baik, ketepatan komentar atas jawaban yang keliru oleh kelompok lain, mengajukan pertanyaan dan memberikan solusi ketika pertanyaan atau permasalah yang diajukan guru maupun siswa telah magalami kemajuan yang berati. Jika saja dikompirmasi pada tarap pengambilan keputusan maka tingkat kreaivitas siswa ini disebut baik. Hal 
ini dapat diterima bahwa pada siklus ini siswa telah memahami dan mau menerima metode ini dalam kegiatan belajar mengajar. Adapaun tingkat prestasi belajar siswa terdapat 31 orang atau $65 \%$ siswa yang telah mencapai KKM sedangan sisanya 12 orang atau $35 \%$ siswa belum mencapai KKM. Bila saja tingkatan prestasi siswa ini komfirmasi dengan pengambilan keputusan maka pada tahap ini prestasi belajar siswa digolongkan sedang. Dari gambaran data diatas secara umum bahwa pada tahap ini sudah berhasil secara umum, namun pada variabel lain masih banyak kekurangan. Untuk kepentingan itu penulisan ini dilanjutkan pada siklus ketiga. Hal ini dapat diduga bahwa kreativitas dan prestasi belajar sedang tidak hanya disebabkab oleh faktor siswanya namun faktor guru dan alat evalusi serta lingkungan juga sangat mendukung sehingga penerapan metode ini belum optimal . Adapun kemajuan yang ditunjukkan siswa pada siklus kedua ini antara lain: 1) siswa sudah menunjukkan keterampilan berdiskusi, 2) pertanyaan guru sudah dapat direspon dengan baik oleh sebagian besar siswa, 4) bantuan yang diberikan kepada sesama kelompok dan di luar anggota kelompok telah menunjukkan hasil yang baik, 5) telah mampu memberikan penjelasan kepada siswa lain dengan caranya sendiri meskipun perlu perbaikan, 6) siswa sudah berani mempresentasikan hasil kerjanya meskipun perlu bimbingan, 7) komentar atas jawaban yang keliru oleh kelompok lain telah mulai dapat direfisi oleh kelompok lainya. Dilain pihak alat evaluasi yang dibuat penulis perlu diperbaiki, masih terdapat sedikit jumlah siswa yang mengajukan berbagai solusi ketika menyelesaikan persoalan yang diajukan guru atau siswa maupun kelompok lain, masih sedikit siswa yang menawarkan berbagai cara untuk menyelesaikan persoalan yang dihadapi siswa, secra umum siswa belum mampu menghubungkan materi pelajaran yang sedang dihadapi dengan materi lain,. Untuk kepentigan ini perlu diterruskan pada siklus ke tiga.

\section{Siklus III}

Dalam tahap ini diperoleh gambaran data mengenai aktivitas siswa sebagai berikut dari 32 orang siswa yang dijadikan sebagai obyek penulisan terdapat 6 orang yang terlihat tidak aktif selama kegitan belajar sementara sisanya 33 orang 
telah menunjukkan kemajuan yang berarti. Berarti ada 76,7,1\% siswa digolonkan aktif dan ada 23,3\% siswa tidak katif. Jadi dapat disimpulkan bahwa pada tahap ini tingkat keterlibatan aktivitas belajar siswa digolongkan tinggi. Hal ini dapat diterima bahwa pada tahap ini siswa secara umum sudah dapat menerima metode ini dalam kegiatan belajar megajar dan keaktivan siswa telah dikatakan meningkat dengan pesat pada tahap ini. Hal ini ditandai dengan keterlibat langsung siswa sudah meningkat pesat, siswa berminat dan terampil sebagai presentator, tidak malu mengajukan persoalan yang dihadapi, sebagian besar memiliki catatan dengan rapi, , tidak ngantuk selama kegiatan berlangsung, tidak datang terlambat dan atau sengaja keluar untuk keperluan yang tidak jelas, bantuan yang diberikan kepada sesama kelompok dan tidak ditemukanya bulliying pada tahap ini. Tetapi berkomunikasi lancar dengan sesama kelompok atau diluar kelompok perlu diperbaiki. Selanjutnya pada fokus penulisan mengenai asfek kemandirian siswa diperoleh gambaran sebagai berikut terdapat 36 orang siswa yang memiliki kemajuan yang berarti sementara sissanya 3 orang siswa belum menunjukkan kemandirian bermutu hal ini ditandai dengan banyaknya siswa yang mengajukan pertanyaan dan memberikan solusi ketika pertanyaan atau permasalahn yang diajukan guru maupun siswa. Jika saja dikompirmasi pada tarap pengambilan keputusan maka tingkat kemandirian ini disebut sangat baik. Hal ini dapat diterima bahwa pada kegitan: 1) mengajukan berbagai solusi ketika menyelesaikan persoalan yang diajukan guru atau siswa, 2) ketepatan solusi yang ditawarkan, 3) mampu menerapkan materi yang telah dipelajari dan yang sedang dihadapi, 4) menawarkan berbagai cara untuk menyelesaikan persoalan yang dihadapi, 5) membuat teman diskusi tidak merasa direndahkan, 6) mampu materi pelajaran yang sedang dihadapi dengan materi lain, 7) mampu memberikan penjelasan kepada siswa lain dengan caranya sendiri, 8) mampu berdiskusi dengan baik, ketepatan komentar atas jawaban yang keliru oleh kelompok lain . Adapun tingkat prestasi belajar siswa terdapat 36 orang atau $81 \%$ siswa yang telah mencapai KKM sedangan sisanya 3 orang atau $19 \%$ siswa belum mencapai KKM. Bila saja tingkatan prestasi siswa ini komfirmasi dengan pengambilan keputusan maka pada tahap ini prestasi belajar siswa digolongkan tinggi. Jadi 
dalam penulisan ini dapatlah dikatakan bahwa: 1) metode ini dapat diterima dengan baik oleh seluruh siswa, 2) penulis tidak menemukan bulluying selama kegitan belajar mengajar berlangsung, 3) siswa telah terampil dan terbiasa berdiskusi, 4) siswa terbiasa mempresentasikan hasil kerjanya dengan baik, 5) tidak ditemukan siswa yang memiliki catatan tidak rapi, 6) komunikasi lancar dengan baik sesama kelompok atau diluar kelompok, 7) tidak ditemukan adanya siswa mengantuk selama kegiatan berlangsung, 9) bantuan yang diberikan kepada sesama kelompok telah baik, 10) lebih banyak siswa yang mengajukan ketepatan solusi yang ditawarkan, 11) telah mampu secara umum menerapkan materi yang telah dipelajari dan yang sedang dihadapi, 12) tidak ditemukan perbuatan siswa yang membuat teman diskusi merasa direndahkan, 13) telah mampu memberikan penjelasan kepada siswa lain dengan caranya sendiri. Dari gambaran data diatas secara umum bahwa pada tahap ini sudah berhasil secara umum, kepentingan itu penulisan ini sudah dianggap cukup sampai pada siklus ketiga.Untuk itu metode ini dapat dijadikan sebagai alternatif dalam kegiatan belajar mengajar.

\section{SIMPULAN DAN SARAN}

\section{Simpulan}

1. Penerapan model pembelajaran dinamika kelompok dalam proses pembelajaran khususnya di SMA Negeri 3 Selong tahun pelajaran 2018/2019 pada kelas X IPS-1 dapat meningkatkan kemandirian dan partisipasi siswa.

2. Penerapan model pembelajaran dinamika kelompok dalam proses pembelajaran di SMA Negeri 3 Selong pada kelas X IPS-1 dapat meningkatkan prestasi belajar siswa.

\section{Saran}

1. Untuk guru mata pelajaran matematika hendaknya dapat menerapkan sekenario pembelajaran model dinamika kelompok yang diyakini dapat meningkatkan kompetensi diri dalam pengembangan karir. 
2. Untuk sekolah-sekolah SMA negeri maupun swasta diharapkan model ini perlu dikembangkan oleh guru lain sebagai alternative dalam proses pembelajaran demi terwujudnya mutu proses pembelajaran.

3. Untuk lembaga Dinas Pendidikan dan Kebudayaan sebagai pihak yang berwenang dapat memperkenalkan model dinamika kelompok kepada sekolahsekolah lain untuk dilaksanakan guna mencari model pembelajaran yang tepat.

\section{DAFTAR PUSTAKA}

Alma, Buchari dkk. 2009. Guru Profesional Menguasai Metode dan Terampil Mengajar. Bandung: Alfabeta.

Arikunto, Suharsimi. 2006. Prosedur Penulisan Suatu Pendekatan Praktik. Jakarta : Rineka Cipta.

Arikunto, Suharsimi dkk, 2009. Penulisan Tindakan Kelas. Jakarta : Bumi Aksara.

Faharuddin, Indra. 1988. Pengantar Psikologi Pendidikan. Malang : Lembaga Penerbit IKIP.

Hadi, Sutrisno, 2010 Statistik Jilid II, Yogyakarta, Andi

Ghony, Djunaidi. 2008. Penulisan Tindakan Kelas. Malang : UIN-Malang Press.

Isjoni. 2009. Efektivitas Pembelajaran Kelompok. Jakarta : Grasindo.

Kardiman dkk. 2006. Ekonomi Dunia Keseharian Kita. Yudhistira.

Lie, Anita. 2008. Mempraktikkan Cooperative Learning di Ruang-Ruang Kelas. Jakarta : Grasindo.

Purwanto, M. Ngalim. 2006. Psikologi Pendidikan. Bandung : Remaja Rosdakarya.

Solihatin, Etin dkk. 2008. Kooperative Learning Analisis Model Pembelajaran IPS. Jakarta : Bumi Aksara.

Sujdana, Nana. 1989. Penilaian Hasil Proses Belajar Mengajar. Bandung : Remaja Rosdakarya.

Sukmawati. 2006. Efektivitas Pembelajaran Partisipatif Tehnik Buzz Group Pada Mata Pelajaran Biologi Terhadap Motivasi Dan Prestasi Belajar Siswa Kelas II SMPN I Mataram Tahun 2006. FKIP : UNRAM.

Suprijono, Agus. 2009. Kooperative Learning Teori dan Aplikasi Paikem. Yogyakarta : Pustaka Belajar.

Suprobo, Bambang Hasan Budi Sulistyo. 2007. IPS Terpadu Kelas VIII. Jakarta : Erlangga. 